\title{
OUTLINE FOR PAPERS SUBMITTED TO THE INTERNATIONAL SYMPOSIUM OF THE ANALYTIC HIERARCHY PROCESS
}

\author{
Jacek Strojny \\ Rzeszow University of Technology \\ Rzeszow, Poland \\ E-mail: jstrojny@prz.edu.pl \\ Anna Prusak (Strada) \\ Cracow University of Economics \\ Kraków, Poland \\ E-mail: anna.prusak@uek.krakow.pl
}

\begin{abstract}
The main objective of this study was to apply the AHP method to identify the most important factors of local development in one of the districts of Southern Poland, Nowy Targ. The hierarchical model has been constructed based on the relevant literature and consultations with the workers of the District Office. The main criteria consisted of four areas of local development, including potential of the society, economic potential, environmental potential and institutional potential. 14 workers of the District Office participated in the survey. Individual results were aggregated using the AIP procedure (aggregation of individual priorities). The results indicate that the most important factors influencing local development at the district level are Entrepreneurship $(10,4 \%)$, Tourist attractions $(9,03 \%)$ and Demographic potential $(8,78 \%)$. The research also revealed a range of problems related to group decision-making in public administration.
\end{abstract}

Keywords: public administration, strategic management, AHP.

\section{Introduction}

The introduction of the mechanism of self-governance in Poland was one of the most important episodes for the first post-communist government after transition period in 1989/1990. Three tiers of territorial government have been established: regional (16 regions), district (315 districts) and municipal (2500 municipalities). Local authorities at each level have a range of instruments to influence local and regional development processes. In order to improve organizational efficiency in using these instruments, local governments implement various methods and tools. One of them is the Analytic Hierarchy Process (AHP), the most widely used (by scientists and practitioners) decision support technique. The main advantages of this method are its simplicity and applicability to many decision-making problems. The paper presents the application of the AHP to identify the most important factors of local development in one of the districts of Southern Poland, namely Nowy Targ.

\section{Literature Review}

International Journal of the 
There has been no AHP study, which can be compared directly with the research reported in the current paper. However, the AHP technique has been applied in many fields to solve a wide range of decision problems (Vaidya \& Kumar, 2006). Notably, the method has been used successfully in many commercial companies, including IBM and British Airways. The AHP was also used by the US Department of Defense to make important military decisions (Saaty, 2008). Over 400 examples of hierarchical models have been collected and discussed in (T.L. Saaty \& Forman, 1992). They represent a variety of decision-making problems, including economics, business, healthcare, and public administration. The elements of our AHP model have been identified based on the relevant documents concerning public administration in Poland (Municipal Government Act of 1990, District Government Act of 1998, Regional Government Act of 1998), followed by the consultation of the experts (workers of the District Office in Nowy Targ) who participated in the study.

\section{Objectives}

The main objective of this study is to identify the most important, strategic factors influencing local development processes in Nowy Targ, the mountain district in Southern Poland. Specific research objectives include the following:

1. To develop a universal and multilevel decision model containing various aspects of local development processes in the district of Nowy Targ, such as socio-economic, environmental and anthropogenic factors.

2. To produce a list of specific and measurable strategic factors influencing development processes in Nowy Targ, and to identify those with highest priorities.

3. To provide relevant suggestions on how these factors can be implemented (and which should be implemented in the first place).

4. To demonstrate a new approach to decision-making in public administration (at the level of local government) and describe major problems with real-life decisions solved in the group settings.

It is worthy to note that the above objectives have not only scientific value, but also

\section{Research Design/Methodology}

\subsection{The AHP model}

The paper presents the application of the AHP method to prioritization of factors influencing local development processes in local government in Poland. It has been identified as a real-life problem raised by the workers of the District Office in Nowy Targ, Southern Poland. First, the hierarchical model has been developed with the following main goal: "Selection of the most significant factors influencing various aspects of local development - what should be the main focus in the future development strategy". The main criteria consisted of four areas of "local development potential", specifically:

1. Potential of the society - characteristics of the citizens of the district, including competencies, relationships and demographic potential.

2. Economic potential - characteristics of the private sector, including production potential, innovativeness and entrepreneurship.

3. Environmental potential - natural resources and infrastructure, determining quality of life as well as conditions for tourisms, agriculture and mining. 
4. Institutional potential - characteristics of public administration, including competencies and the quality of work.

The complete hierarchical model is presented in Figure 1.

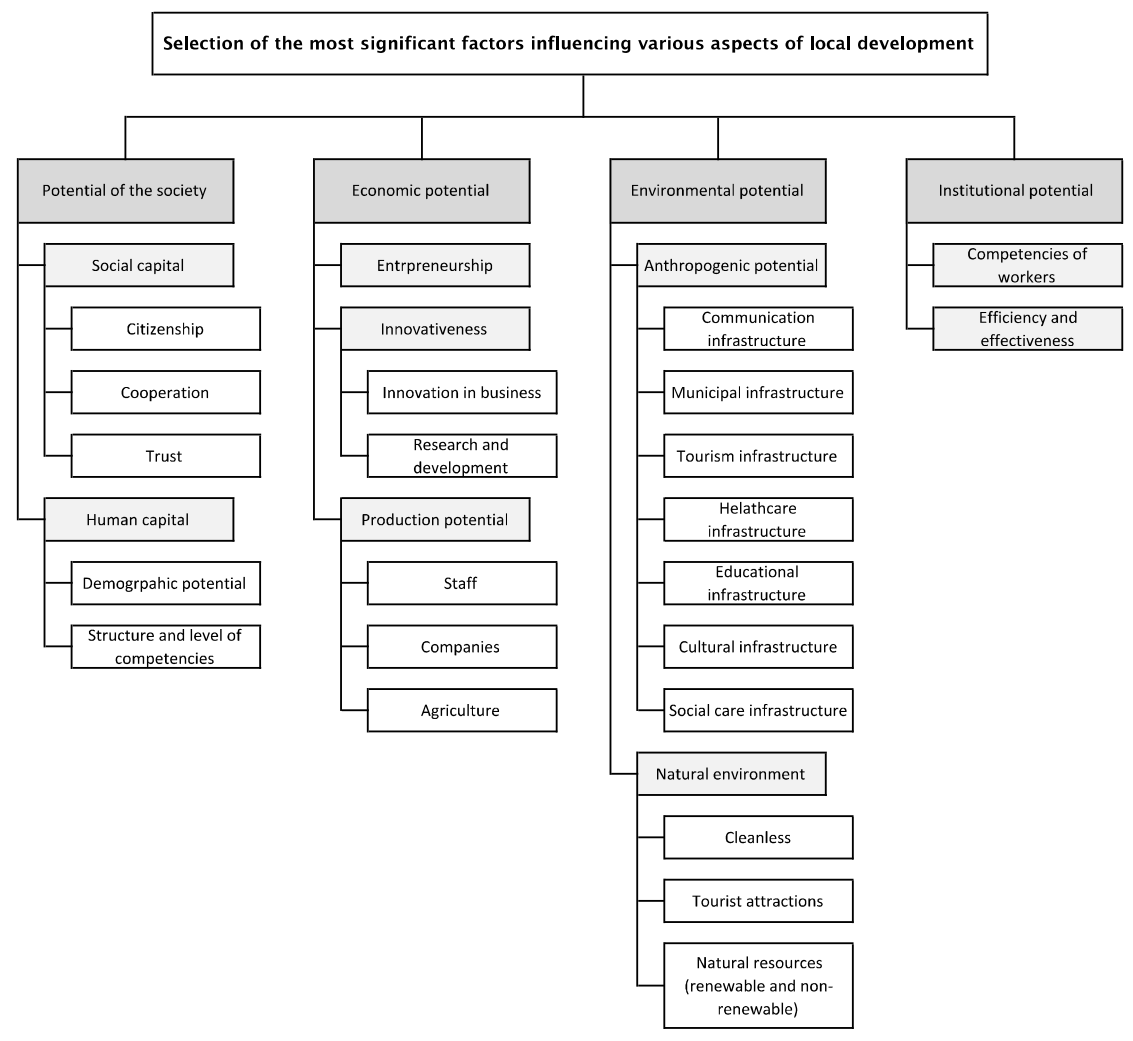

Figure 1. The AHP model regarding factors influencing local development in Poland at the district level

All elements of the hierarchical model (goal, criteria and subcriteria) have been identified based on the legal acts regulating this tier of local government (District Government Act of 1998), with consultations of the relevant experts.

\subsection{Data collection}

The surveyed group consisted of 14 decision makers employed in the Dictrict Office in Nowy Targ, and was conducted during their common meeting. Although the AIJ procedure was more appropriate for a uniform group (consensus-based, aggregation of individual judgments using the same questionnaire for all the respondents), they preferred to complete the questionnaires individually. Subsequently, the separate models have been constructed and AIP procedure (aggregation of individual priorities) was applied using arithmetic mean.

\section{Data/Model Analysis}


Figure 2 demonstrates that the most important factor influencing local development at the district level is Entrepreneurship (10,4\%), followed by Tourist attractions $(9,03 \%)$, Demographic potential $(8,78 \%)$, Innovation in business $(7,92 \%)$, Clean environment $(7,13 \%)$ and Competencies $(6,65 \%)$. These aspects should constitute the main directions for strategic interventions in the years 2015-2022. Factors of little importance (below $1 \%)$ include Cultural infrastructure $(0,82 \%)$ and Social care infrastructure $(0,87 \%)$.

Figure 2. Global priorities of factors influencing local development

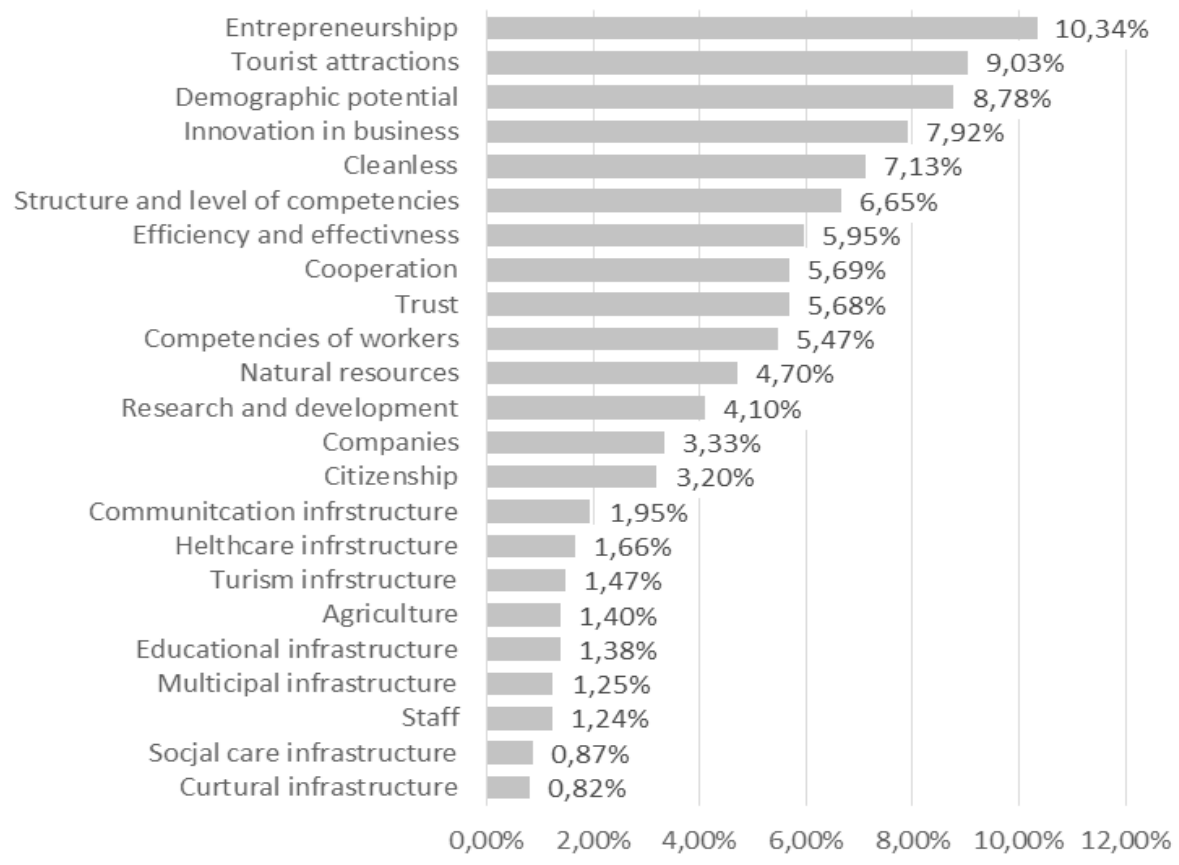

\section{Limitations}

The major limitation of the reported study was difficulty to obtain the consistent judgments from all the respondents. It forced us to exclude several questionnaires from the analysis. Another limitation was disagreement of the respondents on data collection procedure - whether judgments are to be expressed collectively and aggregated using AIJ procedure, or independently (AIP procedure). As most of them preferred to fill in the AHP questionnaires independently, the AIP was finally used, although the group was rather homogenous, implying that reaching the consensus might be a better solution. Last but not least, it was difficult to implement the results into a real-life strategy of local development due to the previous commitments made prior to the AHP study.

\section{Conclusions}

The following conclusions have been drawn from the study with relation to the research objectives: 
1. The AHP model was found helpful in structuring and describing a complex, real-life decision-making problem of local government in Southern Poland district of Nowy Targ: to identify the most important factors influencing local development processes.

2. The highest priority factors (Entrepreneurship, Tourist attractions and Demographic potential) should be the main directions of local development strategy 2015-2022. Subsequently, activities of the District Office should direct particular efforts to these strategic areas, including financial resources.

3. The model and results of the study may serve as a material for comparative analysis with other similar districts and indicate areas for potential improvement.

4. The research allowed identification of the problems related to group decision-making process using the AHP in public administration. One of them was selection of the respondents (experts).

\section{Key References}

District Government Act 1998, Poland (Ustawa z dnia 5 czerwca 1998 r. o samorządzie powiatowym) (1998).

Municipal Government Act 1990, Poland. (Ustawa z dnia 8 marca 1990 r. o samorządzie gminnym) (1990). Poland.

Regional Government Act of 1998, Poland (Ustawa z dnia 5 czerwca 1998 r. o samorządzie województwa) (1998). Poland.

Saaty, T. L. (2008). Relative Measurement and Its Generalization in Decision Making. Why Pairwise Comparisons are Central in Mathematics for the Measurement of Intangible Factors The Analytic Hierarchy/Network Process. RACSAM (Revista de La Real Academia de Ciencias Exactes, Fisicas Y Naturales. Serie A. Matematicas), 102(2), 251-318.

Saaty, T. L., \& Forman, E. H. (1992). The Hierarchon: A Dictionary of Hierarchies (1st ed., p. 570). Pittsburgh: RWS Publications.

Vaidya, O. S., \& Kumar, S. (2006). Analytic hierarchy process: An overview of applications. European Journal of Operational Research, 169(1), 1-29. 